\title{
Millenial Enterpreneurship Creative Digital Economics Based on Aceh's Local Achievements Pandemic Time Covid-19
}

\author{
Kamaruddin Hasan ${ }^{1 *}$, Harinawati ${ }^{1}$, Sufi $^{2}$, Awaluddin Arifin ${ }^{1}$
}

${ }^{1}$ Department of Communication Studies, Faculty of Social and Political Sciences, University of Malikussaleh
2 Business Administration Study Program, Faculty of Social and Political Sciences, University of Malikussaleh
${ }^{*}$ Corresponding author. Email: kamaruddin@ @unimal.ac.id

\begin{abstract}
This research refers to the results of community service through the Entrepreneurship Development Program (PPK) during 2020 in Aceh Province, especially Lhokseumawe City and North Aceh for millennial young businesses. The constructivist paradigm, descriptive qualitative approach becomes the basis of the research. Primary and secondary data sources were obtained through observation, interviews, documentation, focus group discussions (FGD), through education and training, family gathering, capacity building and the revolving capital process. Data analysis is done simply by reducing, presenting and concluding. The theoretical basis, concepts and models used include SWOT analysis, business communication, marketing, digital business, creative economy, millennial concepts and local activism. the results of the research show that strengthening the spirit of entrepreneur among millennial Aceh during the Covid 19 pandemic with a digital-based creative economy based on Aceh local wisdom really needs to be improved and strengthened. Fostering and strengthening a creative entrepreneurial spirit as the new strength of the provinces of Aceh and Indonesia, not only in the spirit but also on a shared mission and undertaking to create identitybased and local wisdom from every product and service work of the nation's children Millennial generation is a storehouse of creativity in the development of the creative economy with digitalization based on local wisdom. The Millennial Generation is a productive resource with creative ideas that can open various types of businesses both in producing products and services on the basis of local wisdom. Can assist the government and private sector in reducing unemployment at the level of the productive workforce. The conclusion of the research is that the more and more Acehnese millennials who are involved in the world of pro-and-glorious entrepreneurship with the foundation of digitalization and based on local wisdom, the more productivity will be generated so that it will have a positive impact on the development of improving the welfare and local economy of Aceh and the national.
\end{abstract}

Keywords: Entrepreneurship Development Program (PPK), Business Communication Digital, Entrepreneurship Millenial, Creative Economy, Aceh Local Wisdom

\section{INTRODUCTION}

As a brief background, that there is no nation that is prosperous and respected by other nations without economic progress. Economic progress will certainly be achieved if there is a strong entrepreneurial spirit and spirit from its citizens. Entrepreneurship in the business world has been widely used as a choice for business people. Entrepreneurs are considered to have the ability to be independent and successful, and even provide job opportunities. Entrepreneur, not only allows people to do something according to what they want, but in addition, entrepreneurs will get financial freedom and sufficient time to do various activities that are liked with friends and family. Entrepreneurship is the right choice that many people look at. With entrepreneurship, it is not only possible to do something in accordance with what you want, but also can open yourself up to increase fighting spirit and motivation, optimize all existing potentials, interests and abilities.

Efforts to strengthen, optimize, increase the quantity and quality of entrepreneurship for Acehnese millennials continue to be encouraged, synergized both 
from local and central governments, universities, private parties or companies, non-governmental organizations or non-government organizations (NGOs) at home and abroad and other stakeholders. This effort will not be in vain when all stages are in accordance with a good management process. Starting from planning, implementing, mentoring, controlling, monitoring and evaluation.

Program Pengabdian Masyarakat - Program Pengembangan Kewirausahaan (PPM-PPK) from the central government of the Ministry of Education and Culture as an example. The Program Pengembangan Kewirausahaan (PPK) from the central government by the Malikussaleh University Be_Entrepreneur team, is packaged in the theme be_enterpreuneur; creating tough-spirited young entrepreneurs.

Based on the brief background above, what is a problem in this research and is urgent to do, among others, is how to invite all Acehnese millennials to maximize their potential in growing an entrepreneurial spirit with the concept of a digitalized creative economy based on local wisdom. How are the efforts of tenants who are members of PPM-PPK Be Entrepreneur, to explore the local potentials of Aceh's local wisdom as products and services for creative businesses on the basis of digital business communication by utilizing information and communication technology then how to develop digital business communication strategies for economic efforts creative based on local wisdom among millennials?

While the research objectives are formulated as follows: 1. To foster enthusiasm, motivation and entrepreneurial spirit among Acehnese millennials. 2. To restore the value of Acehnese local wisdom in every creative economy endeavor of millennial circles. 3 . Improve the quality of human resources among millennials in the field of creative economy entrepreneurship based on Acehnese local wisdom. 4. Presenting a creative economy development strategy based on local wisdom in facing the digital era. 4. Presenting views of special communication in the field of digital business communication in the strategy of developing a creative economy business based on Acehnese local wisdom.

The benefits of this research are useful for: 1 . As a scientific discourse on entrepreneurship. The creative economy of the digital era based on local wisdom is an effort to empower human resources. 2. As a form of efforts to develop the creative economy of the digital era in facing modern markets while maintaining the philosophy and spirit of locality. 3. As an alternative strategy for business practitioners - millennial tenants who are members of Be_Entrepreneur Unimal in developing, preserving and expanding business networks and markets. 4. Adding literature for academics in examining issues of Millennial Entrepreneurship, digital era business communications and the development of a creative economy based on local wisdom.

\section{LITERATURE REVIEW}

As a basis for the literature review in this study, several theories, concepts and models were used. Among others, SWOT analysis, Digital Business Communication, digital literacy, Creative Economy based on local wisdom and millennial concepts, Marketing Mix and Model A.I.D.D.A.

\section{METHODOLOGY}

This study uses a constructivism paradigm with a descriptive qualitative approach. Lexy J. Moleong (2010: 6: 168) defines qualitative research as research that intends to understand the phenomena experienced by research subjects. explains that researchers are planners, implementers of data collection, analysis, data interpretation, and in the end the researcher becomes the reporter of the research results. That research with the constructivist paradigm studies a variety of realities constructed by individuals and the implications of these constructs for their lives with others. According to Patton (2002) there are three types of data used in qualitative research, namely interviews, direct observation, and written documents. This research was conducted by exploring individual experiences and feelings about hope. For this reason, extracting information from informants is extracted qualitatively not quantified by calculating the percentage and answers to fixed questions. While data collection techniques, by observation, interviews, document and literature study, focus group discussions. Writing and data analysis techniques, according to Bogdan and Tylor (Moleong; 2010: 280), Analysis and writing of reports is another important process that must be carried out as well as the field research process. Several things that need to be considered in the analysis and writing process, namely: Snow Ball Informants and Cross Checks and synchronization. This synchronization process also goes hand in hand with the data synthesis and comparison processes. Process of Concise and Abbreviating and conclusion.

\section{RESULTS AND DISCUSSION}

The results showed that the targets of the Program Pengembangan Kewirausahaan (PPK) were millennials, especially active students of Malikussaleh University, including several alumni as productive ages. The targets of productive age, given their behavior, mindset, ways of managing finances and work ethic, are 
the guidelines for the development of these millennials in creative economy and business ventures in the region and the State. In general, it is known that the population of Aceh Province is more than 5 million people in 2019, with the dominant being those of productive age, and Aceh is currently enjoying a demographic bonus period in which the number of productive age population is more than the unproductive age.

Millennials, including students, as after being productive, need to continue to be involved in various entrepreneurship programs. Millennial entrepreneurs with a creative economy based on Acehnese local wisdom began to develop in Aceh, especially Lhokseumawe City and North Aceh. Given the large opportunities and local potential or local wisdom of Aceh that has not been utilized as a creative endeavor.

Until 2020, it is illustrated that creative efforts by maximizing the use of local potential or local wisdom, there are many variants; become a content creator activist from various and various untapped local potentials, by utilizing various new media. Exploring this local potential requires creativity and innovation in the marketing communication process and it is all inherent in today's millennials.

Several variants of creative business from tenants and prospective tenants who are members of the PPK program can be submitted, including culinary businesses, food products, Acehnese snacks, tourism potential content creators, Gayo-Aceh coffee, visual communication design and photography, crafts, product design, fashion, film, documentary, video, event organizer, presenter / host or news anchor, pobcast, printing, advertiser, advertising, copywriter, performing arts; fine arts and others, all have added value or value added, in the process of creative business among the intellectuals.

In the process of running a millennial creative economy product and service business, an understanding of marketing communication is needed. Marketing will be so successful or powerful when combined with effective and efficient communication. How to attract consumers to become aware, know and want to buy goods or services through the communication channels run by tenants.

Communication as an individual process provides a stimulus in both verbal and non-verbal forms to change behavior and behavior. Meanwhile, the purpose of marketing communication is to convey messages to certain target groups in a clear and effective way to carry out communication for millennial creative economy businesses as a community, institution, company or individual. In addition, to convey certain messages related to the products being marketed and then feedback can be obtained from consumers.

In addition, marketing communication cannot be separated from the process of delivering messages addressed to the communicant. An important thing that must always be considered and studied by producers or marketers in the marketing communication process is the process of creating a communication. As it is known that marketing communication is a means used to inform, persuade, and remind consumers, either directly or indirectly, about the products and brands being sold. This includes the digital marketing process with the application of digital technology that forms online channels to the market through websites, e-mail, databases, digital TV and through various other recent innovations including blogs, feeds, podcasts, and social networks that contribute to marketing activities.

In the marketing mix process, Lamb et al (Freddy Rangkuti 2009: 21) describe that the marketing mix is a unique product, promotion and pricing strategy designed to produce mutually beneficial exchanges with the target market. Including how to run the Marketing Mix of each product and service.

The AIDDA model is also applied in millennial creative economy ventures, AIDDA is a simple abbreviation that has been made for a long time as a reminder of elements of the sales process (Kotler and Armstrong, 2001). AIDDA stands for Attention, Interest, Desire, Decision and Action. In marketing communication, it is necessary to formulate the objectives to be achieved from the marketing communication process that will be carried out. After determining the target audience with their perceptions, marketing must determine the response that occurs. The audience response can be in the form of cognitive, affective, behavioral and conative.

In responding to the development of information and communication technology that allows everyone to be connected, the creative economy business run by Malikussaleh University Be-Entrepreneur tenants requires digital literacy. Even within certain limits, everyone can form their own community in the world of internet networks. In line with the concept of Castells, 2000 (Prayoga, K. 2018). it is called a cyber extension. Through this pattern, everyone is connected globally and in turn forms a new social and economic community.

In a professional context, there is the term competence. According to Spencer and Spencer (1993), the term refers to the fundamental characteristics of an individual related to referential criteria in job requirements. Furthermore, it is stated that competence shows how to act, think, or understand the situation 
properly in the long term. In connection with the digital context there is the term digital literacy. In general, digital literacy refers to the ability to use information and communication technology (ICT), to find, evaluate, utilize, create and communicate content / information, with both cognitive and technical skills.

Lipton and Hubble (2016: 13) explain that literacy is not just an elementary ability to read, write and count. Literacy in the modern sense includes language skills, arithmetic, interpreting pictures, computer literacy, and various attempts to gain knowledge. According to Heriyanto. (2017), Digital competencies include knowledge assembly competencies, Computer Ethics, Internet Searching, Content Evaluation, Knowledge Assembly, Data Management, Computer Security, Data Backup, Hypertextual Navigation, and Computer Maintenance.

All tenants and prospective tenants for the Program Pengembangan Kewirausahaan (PPK) who are members of the Malikussaleh University Be_Entrepreneur, run a creative economy business based on Aceh's local wisdom, capacity building is still needed to strengthen individual capacities and millennial creative businesses with various theories, concepts and models.

\section{CONCLUSIONS}

The conclusion can be conveyed that humans with all forms of thought patterns, ideas, creative creativity produce cultural works as a form of creativity that can reflect the spirit of local wisdom in them. Likewise, with what is in the creative economy based on Aceh local wisdom. Creative economy businesses, both in the form of products and services, still require capacity building. The erosion of the existence of local wisdom in every millennial creative economy endeavor can be overcome by replanting the values of local Acehnese wisdom, including the philosophy of harmony inherent in every millennial business multyplier effect. In addition, there is also a need for support from a sustainable local wisdom-based creative economy development strategy, such as an understanding of business, marketing, theories, concepts and models of business communication, digitization, motivation and productivity strategies and others. With optimal millennial efforts, this process will create creative economic efforts for a new cultural generation that upholds the spirit of locality, which will then have an impact on improving the quality of human resources. Tenants and prospective tenants who are members of the Malikussaleh University Be_entrepreneur Program Pengembangan Kewirausahaan (PPK), young Human Resources (SDM) includes resources in creative endeavors, including marketing resources, and modern entertainment resources that contribute to building business culture. a creative based on local Acehnese expertise so that it leads to a creative industry pattern that can penetrate modern markets with harmony and balance.

\section{REFERENCES}

Branan, Tom. 1998. Komunikasi Pemasaran. Jakata: PT Gramedia Pustaka Utama

Burhan, Bungin. (2005). Metodologi Penelitian Kuantitatif Komunikasi, Ekonomi, dan Kebijakan Publik Serta Ilmu-Ilmu Sosial Lainnya, Edisi Pertama. Jakarta, Prenada Media.

Diaz Praditya. (2019). Prediksi Perkembangan Industri E-commerce Indonesia pada Tahun 2022.Techinasia. Diakses 25 Agustus 2019.

Donny B.U. (ed.). (2018). Kerangka Literasi Digital. Jakarta: Siberkreasi - FIRAL - ICT Watch Relawan TIK - Internet Sehat.

Dewi Sad Tanti' Adharis Kuswidiarto, Prosiding: Seminar Nasional Peningkatan Mutu Perguruan Tinggi Universitas Mercu Buana Jakarta Tanjung Benoa-Bali, 29 Nopember 2019. Memetakan Kompetensi Digital Petani Pengguna Platform Promosi dan Pemasaran Digital Agribisnis. Mapping Digital Farmers' Competency as Digital Agribusiness, Promotion and Marketing Platform Users, Program Studi Ilmu Komunikasi, Universitas Mercu Buana, Jakarta

Departemen Perdagangan Republik Indonesia. 2008, Pengembangan Ekonomi Kreatif Indonesia 2025: Rencana Pengembangan Ekonomi Kreatif Indonesia 2009 - 2025".

Heriyanto. (2017). "Kompetensi Digital sebagai Strategi Peningkatan Pendidikan Tinggi di Era Modern (Studi Deskriptif pada Sekolah Tinggi Agama Buddha Negeri Sriwijaya Tangerang Banten)". Seminar Lokal Sekolah Tinggi Agama Buddha Negeri Sriwijaya. Tangerang Banten.

Kotler, Philip. (2002). Marketing Management,Millenium Edition. New Jersey : Pearson Custom Publishing

Kotler, Philip dan Armstrong, 2001, Prinsip-Prinsip Pemasaran, Jilid 1,. Erlangga, Jakarta

Kementerian Komunikasi dan Informatika. (2018). "Kementerian Kominfo Sebut Pengguna Internet Indonesia Capai 54 Persen.

Lipton, Laura, dan Deborah Hubble. 2016. Sekolah Literasi Perencanaan dan Pembinaan. Bandung: Nuansa Cendikia Publishing and Printing.

Latuconsina, Hudaya. 2010. Kreativitas Tanpa Batas Menuju Ekonomi Kreatif Berbasis Insan Kreatif. Cetakan I. Jakarta: TERAJU. 
Mulyana, Deddy. (2001). Metode Penelitian Kualitatif llmu Komunikasi. Cetakan pertama.Bandung: Remaja Rosdakarya.

Moleong, L. J. 2010. Metodologi Penelitian Kualitatif, Bandung: Remaja Rosda karya.

Piliang, Yasraf Amir. 2006. Dunia yang Dilipat. Jakarta: Penerbit Jalasutra.

Puspa Rini \& Siti Czafrani, 2010, Pengembangan Ekonomi Kreatif Berbasis Kearifan Lokal Oleh Pemuda Dalam Rangka Menjawab Tantangan Ekonomi Global, Jurnal UI Untuk Bangsa Seri Sosial dan Humaniora Volume 1.

Prayoga, K. (2018). Dampak Penetrasi Teknologi Informasi Dalam Transformasi Sistem Penyuluhan Pertanian Di Indonesia. JSEP (Journal of Social and Agricultural Economics), 11(1), 46-59.

Prisgunanto, I. (2018). Implementasi Promosi Bauran Komunikasi Pemasaran Kartu Kredit Di Indonesia (Studi Deskriptif Bank Mandiri, HSBC, Citibank, BCA dan BNI). Commed: Jurnal Komunikasi dan Media.

Rangkuti, Freddy. ((2009). Strategi Promosi yang Kreatif dan Analisis Kasus Integrated Marketing Communication. Jakarta: PT. GramediaPustakaUtama.

Spencer, Lyle \& Signe M. Spencer. 1993. Competence at Work, Models For Superior. Performance. Canada: John Wiley \& Sons, Inc.

Siti Nur Azizah dan Muhfiatun (2017) Pengembangan Ekonomi Kreatif Berbasis Kearifan Lokal Pandanus Handicraft dalam Menghadapi Pasar Modern Perspektif Ekonomi Syariah (Study Case di Pandanus Nusa Sambisari Yogyakarta) Fakultas Ekonomi Bisnis dan Islam (FEBI) Universitas Islam Negeri Sunan Kalijaga, Indonesia. APLIKASIA: Jurnal Aplikasi Ilmuilmu Agama ISSN 1411-8777 | EISSN 25982176 Volume 17, Nomor 2, 2017. 